\title{
Tracking the narrow roads of gene land
}

\author{
J. J. Boomsma' ${ }^{1}$ \\ Published online: 16 December 2019 \\ (c) International Union for the Study of Social Insects (IUSSI) 2019
}

Keywords William D. Hamilton $\cdot$ Social evolution $\cdot$ Hamilton award $\cdot$ Social insects $\cdot$ Inclusive fitness

I am very grateful and deeply honoured to receive the 4 th Hamilton Award of the IUSSI at this wonderful Congress in Guarujá, Brazil. Apart from saying thank you to the Union for entrusting me with this award, I would like to share some observations on my relationship with social insects and on Bill Hamilton's fundamental importance that seem fitting to the occasion.

Ants may well have provided my first enlightenment in natural history, when I was lifting slabs in our garden as a 9-year-old lad and observed their huge gallery systems in great wonder: Their neatly laid-out brood sorted according to size and the massive numbers of winged queens and males, ready to fly off in response to my disturbance, seemed to be a quintessential example of organizational perfection.

As so often in people's lives and careers, it was a coincidence that I became professionally involved with social insects. About 15 years after my childhood, ant-encounters, a series of haphazard events had drifted me into pursuing MSc degree work on ant ecology: initially as a descriptive community ecologist, but my interests changed when I read that ant queens store sperm for a life time that can last up to three decades without queens ever mating again. Later, I came to realize that ants had invented sperm banks at ambient temperature, where humans need liquid nitrogen.

A series of fortuitous events made me aware that newly mated queens can often be reared in mass culture (Fig. 1) and that genetic markers, the now almost 'prehistoric' allozymes, had become available to reconstruct the genotypes of the fathers that contributed stored sperm cells to the worker offspring of a queen. I became totally intrigued by the scientific possibility of reconstructing the hidden sex lives and family structures of ants and other social insects.

$\checkmark$ J. J. Boomsma

JJBoomsma@bio.ku.dk

1 Centre for Social Evolution, Department of Biology, University of Copenhagen, 2100 Copenhagen, Denmark
After those early explorations, it was a small step to later include symbiotic partnerships with fungi and bacteria, allowing very general questions about cooperation and altruism to be addressed. It made me realize that one can only understand the positive synergies of social interactions after having stared the possible conflicts that threaten them in the face.

Most senior organismal biologists consider Bill Hamilton as the most important evolutionist of the second half of the 20th century, but many graduate students now appear to take that for granted or seem sceptical, because they do not directly need Hamilton's rule for their research. Especially for them, a few words on why knowing your Hamilton is as important as knowing your Darwin and your Mendel.

Around 1960, when Hamilton started his PhD work, the architects of the modern synthesis had successfully reconciled Darwin's fundamental concept of adaptation through natural selection with Mendel's equally ground-breaking insight that genes are particles and that their inheritance is not an unspecified blending process as Darwin had assumed. Nobody, however, had a concept of how genes affect the evolution of social interactions or even an inkling that this question was of fundamental importance.

It was Bill Hamilton who provided biology with a general and universally applicable theory of social adaptation (Fig. 2) (Hamilton 1963, 1964a, b). His 'gene's eye view' of social evolution forever changed the way we think about cooperation for mutual benefits and about the conditions under which reproductive altruism can evolve. All research in our IUSSI community ultimately revolves around questions of cooperation and altruism, because that is what social insects fundamentally do.

This quote from Richard Dawkins (2013, p. 197) summarizes the significance of Hamilton's contribution very succinctly:

Hamilton's theory, now often labelled 'kin selection' (Maynard Smith's name, not Hamilton's own) 


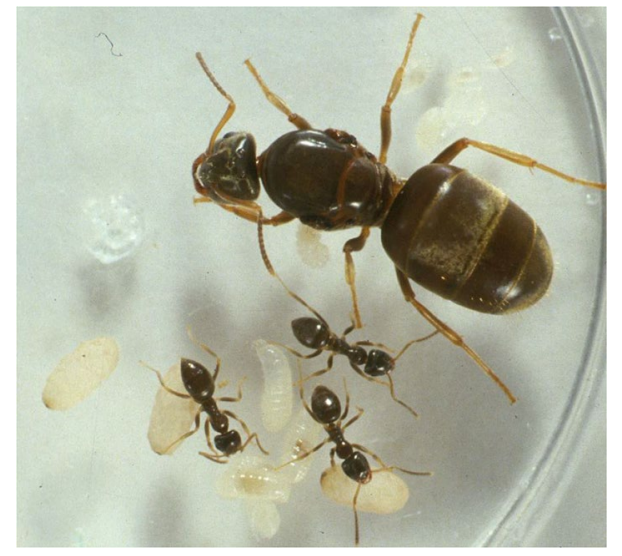

Fig. 1 A ca. 3-months-old colony of Lasius niger, Europe's most common ant, in a petri-dish: The founding queen, her first minute workers, pupae and younger brood, all reared on the queen's body reserves and a plug of moist cotton wool. The workers in a colony of L. niger usually have one or two fathers (image by the author)

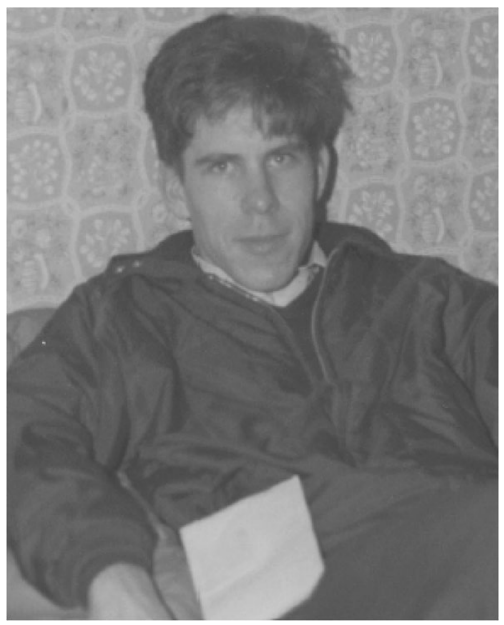

Fig. 2 William D. Hamilton in 1967, a few years after he published his three seminal papers $(1963,1964 a, 1964 b)$ on inclusive fitness theory. Courtesy of the family of William D. Hamilton; (C) British Library Board

follows directly from the neo-Darwinian 'Modern synthesis' directly, in the sense that kin selection is not an extra, not an addition bolted on to the neoDarwinian synthesis: it is a necessary part of the synthesis. You cannot divorce kin selection from neo-Darwinism any more than you can divorce the Pythagorean theorem from Euclidean geometry.

As a key concept, Hamiltonian inclusive fitness theory is so general because, it uses the direct and indirect propagation of genes coding for social traits across all the levels at which natural selection operates; proving that principle was and continues to be a truly ground-breaking insight.

All fundamental theories of science have in common that they explain an enormous amount of natural complexity with very few parsimonious principles. That is what Newton mechanics achieved and what Albert Einstein and Niels Bohr fundamentally improved upon when they extended the Newtonian paradigm with new theories that work at the speed of light and at the scale of fundamental particles. Einstein and Bohr showed that Newton mechanics was a special case of a more encompassing theory, which gave physics countless new and often counterintuitive predictions. Some of these were only testable a century later, as we recently, experienced with the empirical demonstration of gravitational waves.

Theory that offers such encompassing insights is the best science can achieve, because such kind of theory imposes significant odds upon its predictions, which maximizes the likelihood for these predictions and the chains of logic on which they rest, to be empirically refuted. Einstein and Bohr risked their reputations when they proposed their theories and they were vindicated. Bill Hamilton was an equally daring scientist. His rule $(\mathrm{rb}>\mathrm{c})$ is as simple as Einstein's $e=\mathrm{mc}^{2}$ and he was convinced that the logic of his reasoning could hardly fail to be correct, if the modern evolutionary synthesis was to have any merit. He states that very clearly in one of his autobiographical essays (Hamilton 2000):

My ideas about kin selection were at last written down and submitted to a journal. I was pretty sure they were right, that is, I was sure they were correctly argued. If they were it was clear that no amount of evidence from nature would make them wrong; or, if it did, then at least for my comfort, Darwin's and Fisher's versions of evolution, perhaps along with all of Mendel's genetics, would have to come crashing down as well.

As a person, Hamilton combined very imaginative and carefully phrased science with a reckless romantic disregard for his personal health and safety. In his later years that produced legendary stories about his bike-riding habits through the busy streets of Oxford (Grafen 2004) and it probably contributed to his untimely death in 2000 after an expedition to the heart of Africa.

The recognition of his work was initially slow in coming, which understandably frustrated him. Brazil and the researchers around Warwick Kerr deserve great credit for having hosted the young Bill Hamilton (Fig. 2) on two occasions, when he sought adventurous relief in tropical fieldwork to get away from his little inspiring British academic environment. While in Brazil, Hamilton tried to unravel the social secrets of the swarm-founding polistine wasps. That group remains understudied to the present day, perhaps because few can muster the Hamiltonian courage required 
to engage with these awe-inspiring creatures. A better comparative understanding of their societies remains a top priority for further evaluating the general validity of inclusive fitness theory.

Table 1 Inclusive fitness theory has been important in understanding a range of behavioural phenomena. Reprinted by permission from Nature/Springer: Nature

\begin{tabular}{llll}
\hline Research area & Correlational & Experimental & $\begin{array}{l}\text { Theory- } \\
\text { data } \\
\text { interplay }\end{array}$ \\
\hline Sex allocation & Yes & Yes & Yes \\
Policing & Yes & Yes & Yes \\
Conflict resolution & Yes & Yes & Yes \\
Altruism & Yes & Yes & Yes \\
Spite & Yes & Yes & Yes \\
Kin discrimination & Yes & Yes & Yes \\
Parasite virulence & Yes & Yes & Yes \\
Parent-offspring conflict & Yes & Yes & Yes \\
Sibling conflict & Yes & Yes & Yes \\
Selfish genetic elements & Yes & Yes & Yes \\
Cannibalism & Yes & Yes & Yes \\
Dispersal & Yes & Yes & Yes \\
Alarm calls & Yes & Yes & Yes \\
Eusociality & Yes & Yes & Yes \\
Genomic imprinting & Yes & Yes & Yes \\
\hline
\end{tabular}

Inclusive fitness theory and eusociality. Brief communications arising from M.A. Nowak, C.E. Tarnita and E.O. Wilson (2010); Abbot et al. (2011)
As my example of Newton, Einstein, and Bohr illustrated, major advances such as inclusive fitness theory (Table 1) need even more fundamental challenges to ultimately be cornered as representing a special case of an even more broadly founded theory. Such a step down the paradigmatic hierarchy has not yet happened for inclusive fitness theory in spite of a misguided recent attempt to discredit it (Nowak et al. 2010). That challenge, rebutted by ca. 150 evolutionary and behavioural biologists (Abbot et al. 2011), many of them from our IUSSI community, failed because it did not produce a single novel testable prediction and it did not allow recapturing even a single social adaptation that was already predicted and empirically validated by inclusive fitness theory.

The 48 yesses in Table 1 illustrate the tremendous support for inclusive fitness theory and justify paraphrasing Dobzhansky's famous statement as "Nothing in social evolution makes sense except in the light of inclusive fitness". If inclusive fitness theory is an integral part of the modern evolutionary synthesis, it cannot be controversial, unless the entire foundation of biology is flawed. But that does not mean relatedness is always relevant. If relatedness is zero, indirect Hamiltonian fitness is zero and inclusive fitness simply reduces to direct Fisherian fitness. That still allows mutualistic cooperation to evolve, provided commitment between partners is sufficiently strong.

Bill Hamilton's written legacy is available in three volumes (Fig. 3) that have the inspiring title 'Narrow Roads of Gene Land'. The narrow refers to the stringency of inclusive fitness theory and the gene land to the 'gene's eye view of evolution' behind it. The theory applies from microbes to men and the available evidence so far confirms that it usually
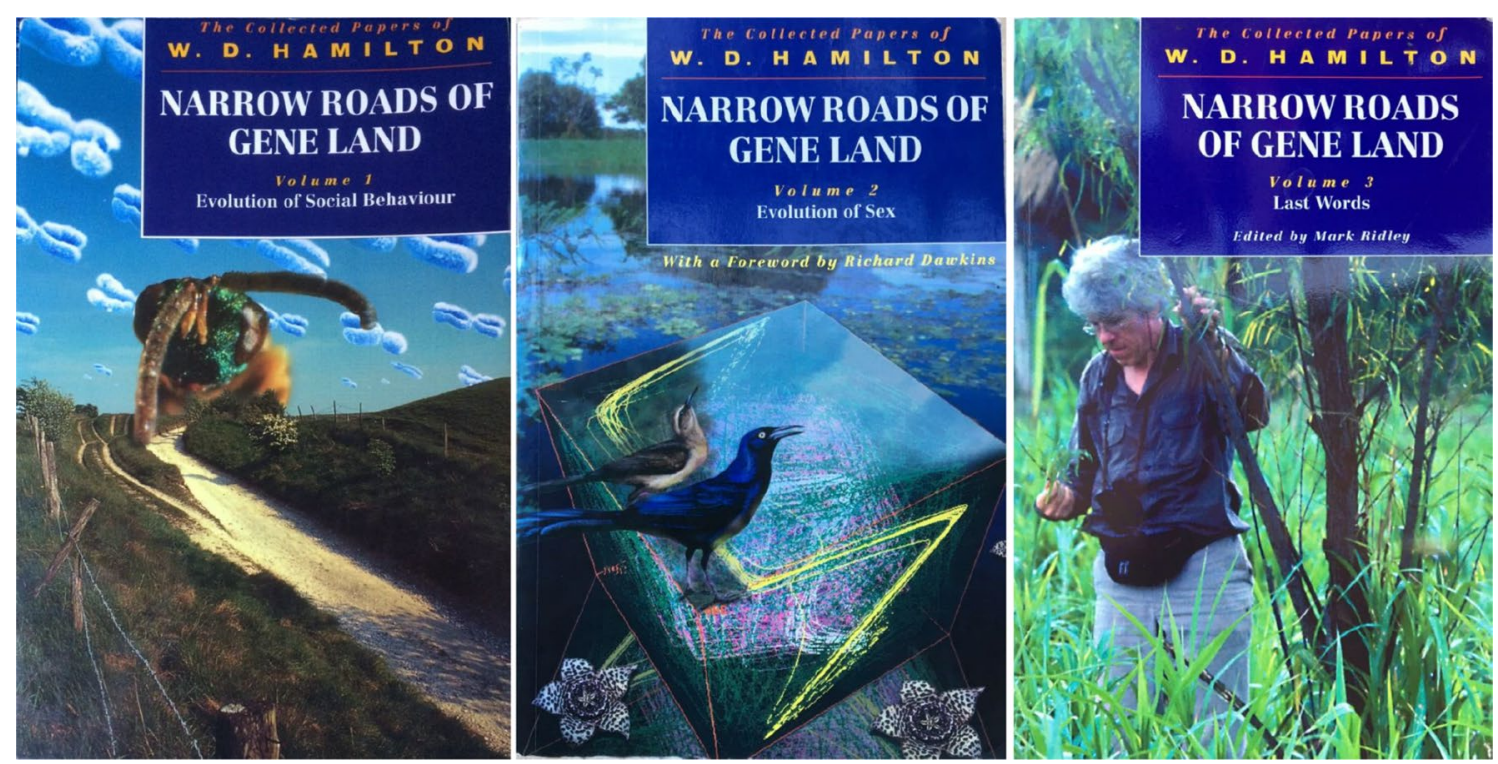

Fig. 3 William D. Hamilton's three volumes of collected papers with autobiographical introductions in Volumes 1 and 2 and historical retrospectives by others in Volume 3 (Hamilton 1996, 2001; Ridley 2005). Covers published with permission from Oxford University Press 
works (Table 1). The only partial exception that we might allow is the social behaviour of our own species, because we continue to be gradually domesticated by cumulative culture, unlike any other organism.

Some find the inclusive fitness paradigm depressing, because it removes the illusion that anything in nature is benign by default. Others find that insight gratifying and are happy to rely on Dawkins' (1976, p. 59) assessment of our unique human potential to resist our genetic legacy:

Not only are our brains in charge of the day-to-day running of survival machine affairs, they have also acquired the ability to predict the future and act accordingly. They even have the power to rebel against the dictates of their genes, for instance in refusing to have as many children as they are able to.

That form of rebellion means that human societies can solve social problems by creating and maintaining non-corrupt and democratically controlled institutions. Our species has gradually improved in doing precisely that often against significant odds and handicapped rather than helped by our biological endowment. In that wider context it has been intellectually liberating to track the "narrow Hamiltonian roads' for close to four decades and to receive this Hamilton Award in recognition of that effort.

I want to single out two other aspects that have been as inspirational as the Hamiltonian paradigm throughout the years. The first is the IUSSI as a scholarly society: Its quadrennial congresses, its section meetings and the personal interactions that the Union facilitates, which I strongly believe will remain as valuable for shaping junior careers as they have done in the past.

The IUSSI has a rich history going back to the 1950s, when a number of senior entomologists felt that social insect biologists would benefit from understanding each other's research, be it on ants, bees, wasps, termites or other social arthropods and no matter what research approach they were using. Their insight was prophetic, because Hamiltonian inclusive fitness theory would later provide much of the scholarly glue to tie all these disparate fields together. By the time that could happen, the Union was firmly established as an international platform to implement such interdisciplinary agendas.

The second aspect I want to emphasize is the splendid companionship of numerous co-travellers, while I found my ways through the narrow roads of gene land over so many years: able MSc students during my PhD in Amsterdam and inspiring students, peers, and hosts to collaborate with during my postdoctoral work in Utrecht, Oxford and Cornell.

I finally settled down in Denmark and would like to acknowledge my highly dedicated group of graduate students and postdocs during the 9 years in Aarhus, and an even larger group, now also including junior faculty colleagues, when we built the Centre for Social Evolution in Copenhagen. Also instrumental were the interdisciplinary collaborations throughout Europe during the 9 years of EUfunded networks and the 25 years of engagement with the Smithsonian Tropical Research Institute in Panama that made our research on fungus-growing ants possible. Thank you all very much.

\section{References}

Abbot P, Abe J, Alcock J, Alizon S, Alpedrinha JAC, Andersson M, Andre JB, van Baalen M, Balloux F, Balshine S, Barton N, Beukeboom LW, Biernaskie JM, Bilde T, Borgia G, Breed M, Brown S, Bshary R, Buckling A, Burley NT, Burton-Chellew MN, Cant MA, Chapuisat M, Charnov EL, Clutton-Brock T, Cockburn A, Cole BJ, Colegrave N, Cosmides L, Couzin ID, Coyne JA, Creel S, Crespi B, Curry RL, Dall SRX, Day T, Dickinson JL, Dugatkin LA, El Mouden C, Emlen ST, Evans J, Ferriere R, Field J, Foitzik S, Foster K, Foster WA, Fox CW, Gadau J, Gandon S, Gardner A, Gardner MG, Getty T, Goodisman MAD, Grafen A, Grosberg R, Grozinger CM, Gouyon PH, Gwynne D, Harvey PH, Hatchwell BJ, Heinze J, Helantera H, Helms KR, Hill K, Jiricny N, Johnstone RA, Kacelnik A, Kiers ET, Kokko H, Komdeur J, Korb J, Kronauer D, Kummerli R, Lehmann L, Linksvayer TA, Lion S, Lyon B, Marshall JAR, McElreath R, Michalakis Y, Michod RE, Mock D, Monnin T, Montgomerie R, Moore AJ, Mueller UG, Noe R, Okasha S, Pamilo P, Parker GA, Pedersen JS, Pen I, Pfennig D, Queller DC, Rankin DJ, Reece SE, Reeve HK, Reuter M, Roberts G, Robson SKA, Roze D, Rousset F, Rueppell O, Sachs JL, Santorelli L, Schmid-Hempel P, Schwarz MP, Scott-Phillips T, Shellmann-Sherman J, Sherman PW, Shuker DM, Smith J, Spagna JC, Strassmann B, Suarez AV, Sundstrom L, Taborsky M, Taylor P, Thompson G, Tooby J, Tsutsui ND, Tsuji K, Turillazzi S, Ubeda F, Vargo EL, Voelkl B, Wenseleers T, West SA, WestEberhard MJ, Westneat DF, Wiernasz DC, Wild G, Wrangham R, Young AJ, Zeh DW, Zeh JA, Zink A (2011) Inclusive fitness theory and eusociality. Nature 471(7339):E1-E4

Dawkins R (1976) The selfish gene. Oxford University Press, Oxford Dawkins R (2013) An appetite for wonder. Black Swan, London

Grafen A (2004) William Donald Hamilton: 1 August 1936, 7 March 2000. Biogr Mems Fell R Soc Lond 50:109-132

Hamilton WD (1963) Evolution of altruistic behavior. Am Nat 97(896):354-356

Hamilton WD (1964a) Genetical evolution of social behaviour 1. J Theor Biol 7(1):1-16

Hamilton WD (1964b) Genetical evolution of social behaviour 2. J Theor Biol 7(1):17-52

Hamilton WD (1996) Narrow Roads of Gene Land: Evolution of Social Behaviour. Oxford University Press, Oxford

Hamilton WD (2000) My intended burial and why. Ethol Ecol Evol 12:111-122

Hamilton WD (2001) Narrow roads of gene land: evolution of social behaviour. Oxford University Press, Oxford

Nowak MA, Tarnita CE, Wilson EO (2010) The evolution of eusociality. Nature 466(7310):1057-1062

Ridley M (ed) (2005) Narrow roads of Geneland, Volume 3: last words. Oxford University Press, Oxford 